\section{A PSICANÁLISE RESPONDE AOS DESAFIOS DA ADOLESCÊNCIA}

Destinos da adolescência, de Marta Rezende Cardoso e François Marty (orgs.) Rio de Janeiro: 7 Letras, 2008. 204 p.

\section{Maria Teresa de Melo Carvalho \\ Psicanalista. Professora do curso de Especialização em Teoria Psicanalítica da UFMG. \\ Paulo de Carvalho Ribeiro \\ Psicanalista. Professor do Programa de Pós-graduação em Psicologia da UFMG.}

Embora Freud não tenha explorado o tema da adolescência, isto não impediu que o assunto ganhasse terreno nos trabalhos dos primeiros discípulos, constituindo-se, pouco a pouco, como um campo de grande interesse para a psicanálise. A coletânea Destinos da adolescência, organizada por Marta Rezende Cardoso e François Marty, é um testemunho da maturidade atingida pela reflexão psicanalítica sobre esse tema. A coletânea reúne 11 artigos, que primam pela qualidade das reflexões teóricas, pela consistência das pesquisas que lhes deram origem e pelo lastro clínico da maioria de seus autores.

Por se tratar de coletânea que reúne autores brasileiros e franceses, nos oferece também a oportunidade de constatar a maturidade da pesquisa psicanalítica no Brasil, que não se restringe mais ao lugar de ouvinte dos pesquisadores dos grandes centros universitários europeus, mas se afirma como sua legítima interlocutora. Destinos da adolescência é a quarta coletânea organizada por Marta Rezende Cardoso que, atualmente, é pesquisadora do CNPq, da Associação Universitária de Pesquisa em Psicopatologia Fundamental e do Núcleo de Pesquisa e Intercâmbio para a Infância e Adolescência Contemporânea. As coletâneas anteriores (Adolescência: reflexões psicanalíticas. Rio de Janeiro: Nau/Faperj, 1999; Limites. São Paulo: Escuta, 2004 e Adolescentes. São Paulo: Escuta, 2006) já mostravam essa iniciativa de interlocução com centros de pesquisa no exterior, incluindo alguns artigos de autores franceses, espanhóis e argentinos.

Os artigos inserem-se em projetos de pesquisas com diretrizes bem definidas e mostram um cuidado especial com a fundamentação metapsicológica. Outro aspecto a ser ressaltado é a atenção dada à prática clínica, tanto de forma direta, como na apresentação e discussão de casos clínicos, quanto por meio de referências e reflexões teóricas sempre conectadas à clínica.

Uma apresentação escrita em conjunto pelos organizadores da coletânea traz uma clara justificativa de seus motivos, de suas diretrizes de pesquisa e um sumário dos trabalhos que a compõem. Em seguida, o artigo de Michele Emmanuelli, "A clínica da adolescência”, serve como uma excelente introdução à obra, ao apresentar 
um apanhado do lugar da adolescência nas elaborações psicanalíticas, seguido de uma síntese dos pontos fundamentais do processo da adolescência, de suas manifestações psicopatológicas predominantes, além de considerar, em linhas gerais, o laço entre adolescência e sociedade. O exame de todas essas dimensões prepara o terreno para uma síntese das modalidades terapêuticas com os adolescentes.

Os artigos seguintes podem ser agrupados, para fins de apresentação, em alguns temas que vão se sucedendo na coletânea. "Entre a infância e o infantil — vicissitudes da adolescência", de Regina Herzog e Iná Susini Mariante, e "O genital, impasses e acesso”, de François Marty, colocam em questão a concepção da adolescência como uma fase bem delimitada da vida do sujeito. O primeiro, abordando a distinção entre a infância e o infantil, tal como promovida por Freud, mostra como a psicanálise superou a ideia, presente no pensamento moderno, de um percurso evolutivo linear que definiria fases do desenvolvimento bem demarcadas. O segundo argumenta que o genital não é simplesmente o término bem-sucedido da organização sexual, mas um processo que se enraíza na infância, constitui-se na adolescência e permanece sempre por elaborar, por se desenvolver durante toda a vida.

Seguem-se os artigos “Transgressão pulsional e geracional: a perpetuação da adolescência” de Marta Rezende Cardoso, "Adolescência sem fim? Peripécias do sujeito num mundo pós-edipiano”, de Joel Birman, "A linguagem do ato: entre o recolhimento narcísico e a busca de objeto", escrito por Florian Houssier e "Distúrbios de comportamento, narcisismo fálico e luta contra a passividade na adolescência”, de Jean-Yves Changnon. Eles abordam um dos aspectos mais importantes da adolescência: a violência e sua relação com a sexualidade e com os laços sociais.

Os comportamentos violentos, muitas vezes excessivamente agressivos, dos jovens em nossa sociedade não cessam de nos surpreender e levam, imediatamente, à demanda de sanção, pela sua dimensão de transgressão da lei. Ora, cada um desses artigos, à sua maneira, nos alerta para a necessidade de levar em conta, aquém do problema da transgressão da lei, embora não independente dele, a relação dessas manifestações violentas com a questão pulsional e com os vínculos libidinais e sociais dos jovens de hoje.

Marta Rezende Cardoso destaca a sedução parental, em sua modalidade de intromissão violenta, no momento da revivência do Édipo, característica da adolescência. O artigo de Joel Birman, de inflexão sociológica, tece considerações relativas às transformações ocorridas na sociedade e analisa seus efeitos sobre a juventude, culminando com a proposição de uma tese que nos conduz a pensar na existência de um "novo paradigma civilizatório” (p. 98) e a indagar se estaríamos entrando num mundo pós-edipiano. Analisando um caso atendido no âmbito de um acompanhamento sócio-judiciário, F. Houssier trabalha suas hipóteses sobre o ato delituoso na adolescência como um sensível indicador da problemática psíquica do jovem deliquente, geralmente ligada a um movimento regressivo e, ao mesmo tempo, a um apelo ao ambiente, próprio das oscilações narcísico-objetais dessa fase da vida. Trabalhando também na intercessão da metapsicologia com a clínica, J-Y Changnon constata o horror à passividade em certos adolescentes de frágil estruturação narcísica que são tidos como hiperativos e violentos e desenvolve ideias bastante originais sobre o motivo 
pelo qual eles não podem parar ou descansar sem que sejam invadidos por afetos traumáticos.

O tema do corpo na adolescência é objeto de reflexão nos artigos de Isabel Fortes, "A adolescência e o corpo: considerações sobre a anorexia", e de Annie Birraux, "Projetar". O primeiro discute as hipóteses encontradas na literatura psicanalítica sobre a anorexia e avança no sentido de mostrar como fracassa, nesse quadro, a tarefa de rearranjo da imagem corporal ante as modificações da puberdade, ao mesmo tempo que é sistematicamente recusado o prazer que poderia advir do alimento materno. Essa recusa representaria o único meio possível de escapar da invasão do olhar da mãe. O segundo trata das dismorfofobias, patologias que condensam diversas questões teórico-clínicas muito bem elaboradas pela autora. A dismorfofobia é vista como um fracasso da projeção, o que leva o sujeito a viver com um objeto mau que o invade e do qual não pode se livrar.

Os dois últimos artigos tratam, por vieses diferentes, da problemática da psicose na adolescência. "Delírios e psicopatologia adolescente”, de Faroudja Hocini, aborda os episódios delirantes agudos da adolescência numa tentativa de situá-los a partir de suas dimensões históricas e psicopatológicas, buscando, assim, superar as concepções defectológicas e prognósticas acerca de seu devir. Considera, também, a importância das referências psicoterápicas e da psicanálise, em particular, para a abordagem desses casos. "Adolescência e tratamento do impossível hoje”, de Ana Beatriz Freire e Fernanda Costa-Moura, resulta de duas pesquisas que privilegiam, em sua fundamentação teórica, a concepção lacaniana do pai como recurso metafórico para enfrentar o impossível advindo da estrutura do significante. Dois casos clínicos são relatados e analisados, ilustrando, em cada uma das situações de pesquisa, o funcionamento dos dispositivos concebidos com o objetivo de possibilitar a suplência da função paterna.

Embora todos os artigos sejam muito claros e tenham seus objetivos bem delimitados, o leitor não deve esperar uma leitura fácil, pois as reflexões são complexas e os argumentos muito elaborados. Mas o esforço de leitura vale a pena, pois à medida que se avança no texto, percebe-se a grande sensibilidade e experiência dos autores, o que culmina com a constatação de que a coletânea nos conduz a lançar um novo olhar sobre alguns dos aspectos mais centrais da adolescência.

Recebida em 13/2/2009.

Aprovada em 16/2/2009

Maria Teresa de Melo Carvalho mmelocarvalho@terra.com.br

Paulo de Carvalho Ribeiro icaro.bhz@terra.com.br 